\title{
Penerapan Asas Batas Minimal Pembuktian Dalam Perkara Hukum Perdata (Studi Putusan Pengadilan Negeri Selong Nomor : 55/Pdt.G/2020/Pn.Sel)
}

\author{
${ }^{1}$ Risdiana, ${ }^{2}$ Habibul Umam Taqiuddin \\ Universitas 45 Mataram, Universitas Nahdlatul Ulama Nusa Tenggara Barat
}

\begin{abstract}
Abstrak. Dalam suatu proses peradilan perdata, salah satu tugas hakim adalah untuk menyelidiki apakah suatu hubungan hukum yang menjadi dasar gugatan benar-benar ada atau tidak. Adanya hubungan hukum inilah yang harus terbukti apabila penggugat menginginkan kemenangan didalam suatu perkara. Apabila penggugat tidak berhasil membuktikan dalil-dalil yang menjadi dasar gugatnya, maka gugatannya tersebut akan ditolak, sedangkan apabila berhasil, maka gugatannya tersebut akan dikabulkan. Dalam perkara Nomor. 55/Pdt. G/2020 alat-alat bukti yang diajukan oleh Para Penggugat untuk membuktikan seluruh dalil gugatannya baik bukti surat maupun surat tidak ada satu pun yang bersesuaian satu dengan lain, sehingga tidak mencapai batas minimal pembuktian. Sebaliknya alat-bukti-bukti yang diajukan oleh Kuasa Hukum Tergugat 1, Tergugat 2, dan Tergugat 3 untuk membuktikan seluruh dalil bantahannya telah bersesuaian satu dengan lainnya dan telah mencapai batas minimal pembuktian. Oleh karena itu Putusan Judex Factie Pengadilan Negeri Selong dalam perkara a-quo adalah sah dan benar berdasarkan hukum karena berdasarkan fakta-fakta persidangan Para Penggugat tidak dapat membuktikan seluruh dalil gugatannya dan Kuasa Hukum Para Tergugat (Tergugat 1, Tergugat 2, dan Tergugat 3) telah mampu membuktikan seluruh dalil bantahannya. Dengan demikian dalam pembuktian suatu perkara yang menentukan di persidangan adalah apakah alat-alat bukti yang diajukan oleh para pihak telah mencapai batas minimal pembuktian untuk membuktikan dalil-dalil baik dalam gugatan maupun eksepsi dan jawaban sesuai dengan adagium hukum pembuktian yang tersirat dalam ketentuan pasal $163 \mathrm{HIR}$ jo. pasal $283 \mathrm{RBg}$ jo. pasal $1865 \mathrm{KUHPerdata}$ yang berbunyi "Barangsiapa yang mengaku mempunyai hak atau mendasarkan pada suatu peristiwa untuk menguatkan haknya itu atau untuk menyangkal hak orang lain, harus membuktikan adanya hak atau peristiwa itu"
\end{abstract}

\section{Kata Kunci : Penerapan Asas Batas Minimal Pembuktian, Perkara Hukum Perdata}

\section{PENDAHULUAN}

Dalam suatu perkara hukum perdata hakim bersifat pasif, oleh karena itu pembuktian dilakukan oleh para pihak dan bukan oleh hakim. Hakimlah yang memerintahkan kepada para pihak untuk mengajukan buktinya. Hakimlah yang membebani para pihak mengenai peristiwa apa yang menjadi pokok sengketa dengan pembuktian (bewijslast burden of proof). Tentang hukumnya tidak perlu diberitahukan kepada hakim oleh para pihak, dan tidak perlu dibuktikan. Hakim dianggap tahu akan hukumnya (ius curia novit). Jadi hakim dalam proses hukum acara perdata terutama harus menemukan dan menentukan peristiwanya atau hubunan hukumnya dan kemudian memperlakukan atau menerapkan hukumnya terhadap peristiwa yang telah ditetapkannya itu.

Kepada siapakah pembuktian itu oleh hakim dibebankan atau siapakah di antara kedua belah pihak yang diharuskan membuktikan?
Dengan perkataan lain bagaimanakah hakim membagi beban pembuktian antara pihak? Penggugat atau tergugatkah yang harus membuktikan?. Mengenai hal tersebut dapat disimak asas pembagian beban pembuktian yang tercantum dalam pasal 163 HIR jo. pasal 283 RBg jo. pasal 1865 KUHPerdata yang berbunyi "Barangsiapa yang mengaku mempunyai hak atau mendasarkan pada suatu peristiwa untuk menguatkan haknya itu atau untuk menyangkal hak orang lain, harus membuktikan adanya hak atau peristiwa itu".

Dalam suatu proses peradilan perdata, salah satu tugas hakim adalah untuk menyelidiki apakah suatu hubungan hukum yang menjadi dasar gugatan benar-benar ada atau tidak. Adanya hubungan hukum inilah yang harus terbukti apabila penggugat menginginkan kemenangan didalam suatu perkara. Apabila penggugat tidak berhasil membuktikan dalildalil yang menjadi dasar gugatnya, maka 
gugatannya tersebut akan ditolak, sedangkan apabila berhasil, maka gugatanya tersebut akan dikabulkan.

Hal ini berarti kedua bahwa kedua belah pihak, baik penggugat maupun tergugat d/apat dibebani dengan pembuktian. Terutama penggugat wajib membuktikan peristiwa yang diajukannya, sedang tergugat ber-kewajiban membuktikan bantahannya. Penggugat tidak diwajibkan membuktikan kebenaran bantahan tergugat, demikian pula sebaliknya tergugat tidak diwajibkan untuk membuktikan kebenaran peristiwa yang diajukan oleh penggugat. Kalau penggugat tidak dapat membuktikan peristiwa yang diajukan ia harus dikalahkan. Sedang kalau tergugat tidak dapat membuktikan bantahannya ia harus pula dikalahkan. Jadi kalau salah satu pihak dibebani dengan pembuktian dan ia tidak dapat membuktikan, maka ia akan dikalahkan (resiko pembuktian).

Kaitannya dengan pembuktian tersebut, maka pembuktian di dalam perkara perdata para pihak harus membuktikan kebenaran dalilnya. Karena di dalam hukum acara perdata, kebenaran yang dicari adalah kebenaran yang bersifat formal artinya bahwa hakim tidak boleh melampaui batas-batas yang diajukan oleh pihak-pihak yang berperkara. Pasal 178 ayat (3) HIR secara tegas menyatakan bahwa "Ia dilarang menjatuhkan keputusan atas perkara yang tak dituntut, atau meluluskan lebih dari apa yang dituntut". Hakim hanya cukup membuktikan dengan memutus berdasarkan bukti yang cukup. Dalam memeriksa suatu perkara perdata hakim setidaknya harus melakukan tiga tindakan secara bertahap yakni: mengkonstantir yakni melihat benar tidaknya peristiwa yang diajukan sebagai dasar gugatan, mengkualifisir peristiwa, mengkonstitu ir yakni memberi hukumnya.

Mengenai alat bukti yang diakui dalam hukum acara perdata secara enumeratif diatur dalam Pasal 1866 KUHPerdata, Pasal 164 HIR yang terdiri dari bukti tulisan, bukti dengan saksi, persangkaan, pengakuan, dan sumpah. Dalam praktek masih terdapat satu macam alat bukti lagi yang sering dipergunakan, ialah "pengetahuan hakim". Yang dimaksud dengan "pengetahuan hakim" adalah atau hal yang keadaan yang diketahuinya sendiri oleh hakim dalam sidang. Misalnya hakim melihat sendiri pada waktu pemeriksaan setempat bahwa benar ada barang-barang penggugat yang dirusak oleh tergugat dan sampai seberapa jauh kerusakannya itu.

Perihal pengetahuan hakim tesebut di atas, Mahkamah Agung dengan keputusannya tertanggal 10 April 1957 No. 213 K/Sip/1955 telah memberi pendapatnya sebagai berikut: "Hakim-hakim berdasarkan pasal 138 ayat 1 bersambung dengan pasal 164 Herziene Indonesisch Reglement tidak ada keharusan mendengar penerangan seorang ahli, sedang penglihatan hakim itu sebagai pengetahuan sendiri di dalam usaha pembuktian' (termuat dalam Hukum, Majalah Pahi 1958 No. 1-2, halaman 63-64). Dari putusan tersebut di atas nampak jelas, bahwa "pengetahuan hakim", merupakan alat bukti. Dalam perkara tersebut di atas, hakim yang bersangkutan mempertimbangkan dan menetapkan sendiri perihal perbedaan yang menurut penglihatannya nampak antara tandatangan yang terdapat di atas sehelai surat bukti dan tandatangan yang bersangkutan yang terdapat pada surat kuasa kepada kuasanya.

Agar alat bukti yang diajukan di persidangan sah bernilai sebagai alat bukti yang mempunyai nilai kekuatan pembuktian (bewijskracht), harus mencapai batas minimal pembuktian. Jika, alat bukti yang diajukan dalam persidangan harus dikesampingkan dalam penilaian pembuktian. Namun tidak jarang putusan pengadilan berbeda dari fakta persidangan dan pembuktian di persidangan, sehingga banyak pihak pencari keadilan yang mempertanyakan mengenai proses pemeriksaan perkara di persidangan.

Sebagai contoh Putusan Pengadilan Negeri Selong Nomor 55/Pdt.G/2020/PN. Sel tanggal 24 November 2020 dimana dalam surat gugatan penggugat yaitu Ibu Tuniah, Nurimin, dan Gazali mendalilkan bahwa tanah warisan keluarga alm. Inaq Masiah alias Pq. Meka 
berupa sebidang tanah sawah terletak di Subak Orong Otak Aik Dusun Tuntang, Desa Teros Kecamatan Labuhan Haji Kabupaten Lombok Timur Propinsi Nusa Tenggara Barat dikuasai secara melawan hukum oleh para tergugat yaitu Inak Yul alias Mislun (Tergugat I), Heri Hadi Kusuma (Tergugat II), dan Amaq Ir (Tergugat III). Dalam pemeriksaan perkara eksepsi dan jawaban dari Tergugat I, Tergugat II, dan Tergugat III yang dalam eksepsinya menyatakan bahwa gugatan para penggugat masuk dalam kategori ne bis in idem, karena pihak dan obyek perkara dalam perkara $a$-quo pernah diputus sebelumnua dalam perkara nomor 9/Pdt.G/1989/PN.Sel dan putusan Nomor 22/Pdt.G/1994/PN. Sel. Dalam amar putusannya dalam eksepsi Judex Factie Pengadilan Negeri Selong menolak eksepsi Para Tergugat (Tergugat I, Tergugat II, dan Tergugat III) dengan pertimbangan hukum bahwa pihak maupun obyek perkara yang terdapat dalam Putusan Nomor 9/Pdt.G/1989/PN. Sel dan putusan Nomor 22/Pdt.G/1994/PN. Sel dengan pihak dan obyek dalam perkara $a$-quo berbeda, sehingga Judex Factie Pengadilan Negeri Selong berpendapat bahwa gugatan para Penggugat bukanlah termasuk ke dalam perkara ne bis in idem. Namun dalam amar putusannya dalam pokok perkara Judex Factie Pengadilan Negeri Selong menolak gugatan para penggugat untuk seluruhnya dan menghukum para penggugat untuk membayar biaya yang timbul dalam perkara ini sejumlah Rp. 1.946.000,- (satu juta Sembilan ratus empat puluh enam ribu rupiah).

Berangkat dari fenomena kasus tersebut, maka Putusan Pengadilan Negeri Selong Nomor 55/Pdt.G/2020/PN. Sel tanggal 24 November 2020 sangat janggal karena seharusnya jika eksepsi Tergugat ditolak, maka amar putusannya dalam pokok perkara seharusnya juga menyatakan menolak eksepsi tergugat bukan menolak gugatan para penggugat untuk seluruhnya dan menghukum para penggugat untuk membayar biaya yang timbul. Berdasarkan fakta tersebut, penuli tertarik untuk mengkaji dan meneliti putusan tersebut dengan mengambil judul "Penerapan Asas Batas Minimum Pembuktian Dalam Perkara Hukum Perdata (Studi Putusan Pengadilan Negeri Selong Nomor : 55/Pdt.G/2020/PN.Sel)".

\section{Rumusan Masalah}

Berdasarkan uraian latar belakang masalah di atas, maka yang menjadi rumusan masalah ini adalah :

1. Apakah alat-alat bukti yang diajukan para pihak dalam perkara perdata nomor : 55/Pdt.G/2020/PN.Sel telah mencapai batas minimal pembuktian?

2. Apakah pertimbangan hukum Putusan Pengadilan Negeri Selong Nomor : 55/Pdt.G/2020/PN.Sel tanggal 24 November 2020 adalah sah dan benar berdasarkan hukum acara perdata ?

C. Analisa penerapan asas batas minimal pembuktian dari alat-alat bukti yang diajukan para pihak dalam perkara Nomor : 55/Pdt.G/2020/PN.Sel

Dalam perkara Nomor : 55/Pdt, G/2020/PN. Sel Para pPnggugat mendalilkan dalam surat gugatannya bahwa Tergugat 1, Tergugat 2, Tergugat 3, dan Tergugat 4 telah melakukan perbuatan melawan hukum dengan cara menguasai harta warisan para penggugat. Untuk itu Judex Factie Pengadilan Negeri Selong memeriksa apakah gugatan tersebut benar-benar merupakan gugatan perbuatan melawan hukum atau tidak. Pengertian perbuatan melawan hukum dirumuskan dalam ketentuan Pasal 1365 KUHPerdata yang meny/atakan bahwa "Tiap perbuatan yang melanggar hukum lain, mewajibkan orang yang menimbulkan kerugian itu karena kesalahannya untuk menggantikan kerugian tersebut". Sesuai dengan ketentuan dalam Pasal 1365 KUHPerdata, maka suatu perbuatan melawan hukum haruslah mengandung unsur-unsur sebagai berikut:

1. Adanya suatu perbuatan.

2. Perbuatan tersebut melawan hukum.

3. Adanya kesalahan dari pihak pelaku.

4. Adanya kerugian bagi korban

5. Adanya hubungan kausal antara perbuatan dengan kerugian. 
Untuk membuktikan dalil-dalil gugatannya Penggugat telah mengajukan bukti surat yang telah diberi materai secukupnya dan telah pula dicocokkan dengan aslinya di persidangan antara lain sebagai berikut:

1. Fotocopy Tanda Pendaftaran Sementara Milik Indonesia atas nama INAQ MASIAHdi Desa Teros Kecamatan Selong Pipil Nomor 403 Persil Nomor 132, diberi tanda P-1;

2. Fotocopy Surat Pernyataan Perdamaian tertanggal 23 September 2013 antara H. MUKSIN dengan SAHID'N/AQ. ADER, SANAAH, ALIMUDIN, MININ dan TUNIAH, diberi tanda P-2;

3. Fotocopy Silsilah Waris INAQ MASIAH Alias PAPUQ MEKA tertanggal 27 Juli 2020, yang dibuat dan ditandatangani oleh TUNIAH, diberi tanda P-3;

4. Fotocopy Surat Keterangan Kematian atas nama INAQ MASIAH Alias PAPUQ MEKA Nomor 143/VII/E/2020, yang diterbitkan Pemerintah Desa Teros tertanggal 25 April 2020, diberi tanda P-4;

5. Fotocopy Surat Keterangan Kematian atas nama AMAQ MASIAH Alias PAPUQ MEKA Nomor 142/VII/E/2020, yang diterbitkan Pemerintah Desa Teros tertanggal 25 April 2020, diberi tanda P-5;

6. Fotocopy Surat Keterangan Kematian atas nama AMAQ UDIN Nomor 144/VII/E/2020, yang diterbitkan Pemerintah Desa Teros tertanggal 25 April 2020, diberi tanda P-6;

7. Fotocopy Surat Keterangan Kematian atas nama AMAQ TUNIAH Nomor 145/VII/E/2020, yang diterbitkan Pemerintah Desa Teros tertanggal 25 April 2020, diberi tanda P-7;

8. Fotocopy Surat Keterangan Kematian atas nama AMAQ MAHDI Nomor 146/VII/E/2020, yang diterbitkan Pemerintah Desa Teros tertanggal 25 April 2020, diberi tanda P-8;

9. Fotocopy Surat Keterangan Kematian atas nama/ SAMAD Nomor 147/VII/E/2020, yang diterbitkan Pemerintah Desa Teros tertanggal 25 April 2020, diberi tanda P-9;

10. Fotocopy Surat Keterangan Kematian atas nama DAHMAN Nomor 148/VII/E/2020, yang diterbitkan Pemerintah Desa Teros tertanggal 25 April 2020, diberi tanda P-10;

Bukti P-1 berupa fotocopy Tanda Pendaftaran Sementara Milik Indonesia atas nama INAQ MASIAHdi Desa Teros Kecamatan Selong Pipil Nomor 403 Persil Nomor 132, yang ditandatangani oleh Kepala Kantor Tjabang Djawatan Pendaftaran dan Padjak Penghasilan Tanah Milik Indonesia di Mataram sehingga bukti tersebut jelas merupakan bukti pembayaran pajak dan bukan bukti hak milik. Berdasarkan fakta sejarah hukum agraria bahwa : "Mengenai tanah-tanah hak milik adat di Jawa, Madura, Bali, Lombok dan beberapa daerah lainnya juga ada kegiatan pendaftaran tanah, tetapi bukan untuk memberikan jaminan kepastian hukum di bidang pertanahan, melainkan diselenggarakan untuk keperluan pemungutan pajak tanah, yaitu "Landrete" atau "Pajak Bumi" dan "Verponding Indonesia" (Fiscal Cadastre)".

Sesuai dengan kaidah hukum dalam Yurisprudensi Putusan MARI No. 34 K/Sip/1960 tanggal 10 Februari 1960 yang menyatakan : "Surat Petuk Pajak Bumi bukan merupakan suatu bukti mutlak, bahwa sawah sengketa adalah milik orang yang namanya tercantum dalam petuk pajak bumi tersebut, akan tetapi petuk itu hanya merupakan suatu tanda siapakah yang harus membayar pajak dari tanah yang bersangkutan", maka pertimbangan hukum Judex Factie Pengadilan Negeri Selong yang memeriksa perkara nomor 55/Pdt.G/2020/PN. Sel pada halaman 28 adalah benar dan sangat beralasan hukum yang menyatakan sebagai berikut:

"Menimbang, bahwa kemudin mengenai alat bukti surat berupa tanda pendaftaran sementara tanah milik Indonesia atas tanah obyek sengketa sebagaimana alat bukti surat bertanda P-1 telah diketahui bahwa terhadap alat bukti surat wajib pajak atas tanah telah ditegaskan dalam Yurisprudensi tetap Putusan Mahkamah Agung Republik Indonesia Nomor 34K/Sip/1960, pada pokoknya menegaskan bahwa Surat Pajak Bumi bukanlah merupakan surat bukti mutlak bahwa bidang tanah tersebut adalah 
merupakan pendaftaran sementara tanah milik Indonesia yang diajukan di muka persidangan tersebut hanyalah merupakan suatu tanda untuk menentukan siapa yang harus membayar pajak dari suatu bidang tanah dan bukan menjamin bahwa orang yang namanya tercantum di dalam surat tanda pembayaran pajak tersebut adalah juga pemilik tanah dan untuk dapat dinyatakan sebagai pemilik tanah diperlukan adanya bukti-bukti lainnya...".

Sedangkan bukti surat lain yang diajukan oleh Para Penggugat P-2, P-3, P-4, P-5, P-6, P7, P-8, P-9, dan P-10 tidak berkualifikasi sebagai alat bukti dan tidak membuktikan dalil gugatan para penggugat karena bukti-bukti tersebut hanya menerangkan mengenai kematian seseorang dan tidak dapat membuktikan peruatan melawan hukum yang dilakukan oleh Tergugat 1, 2, dan 3. Bukti-bukti surat tersebut jelas berkualifikasi sebagai alat bukti surat dalam perkara gugatan waris yang merupakan kompetensi absolut pengadilan agama.

Selain mengajukan bukti-bukti surat,

Para Penggugat juga mengajukan alat bukti 2

(dua) orang saksi di persidangan antara lain sebagai berikut:

1. Saksi Supriadi di bawah sumpah menerangkan di persidangan sebagai berikut:

- Bahwa saksi menjelaskan sekarang ini tanah obyek sengketa dikuasai dan digarap oleh anak dan para ahli waris MUHRIM dan HAJI MUKSIN;

- Bahwa saksi menjelaskan tanah obyek sengketa adalah milik INAQ MASIAH Alias PAPUQ MEKA;

- Bahwa saksi mengatakan setelah meninggal dunia maka tanah obyek sengketa dikuasai oleh MUHRIM dan HAJI MUKSIN, namun pada tahun 2013 tanah obyek sengketa dikembalikan oleh HAJI MUKSIN kepada keturunan INAQ MASIAH;

- Bahwa saksi menjelaskan pernah membuat surat pernyataan perdamaian di Kantor Desa Teros tahun 2013;

- Bahwa setelah HAJI MUKSIN meninggal dunia maka tanah obyek sengketa sampai sekarang telah dikuasai dan digarap oleh MISLUN;

2. Saksi Saprudin di bawah sumpah menerangkan di persidangan sebagi berikut :
- Bahwa saksi menjelaskan tanah obyek sengketa adalah INAQ MASIAH Alias PAPUQ MEKA, dan para penggugat adalah ahli warisnya*

- Bahwa saksi menjelaskan sekarang ini tanah obyek sengketa dikua6sai dan digarap oleh AMAQ IR;

- Bahwa saksi menjelaskan INAQ YUL Alias MISLUN mendapatkan obyek sengketa dari HAJI MUKSIN;

- Bahwa saksi tidak tahu darimana HAJI MUKSIN mendapatkan tanah obyek sengketa;

- Bahwa saksi menjelaskan para penggugat pernah meminta tanah obyek sengketa dikembalikan akan tetapi tidak diserahkan oleh INAQ YUL Alias MISLUN

Berdasarkan keterangan saksi-saksi yang diajukan oleh Para Penggugat di bawah sumpah di persidangan yaitu saksi Suriadi dan saksi Saprudin tidak ada satu pun yang bersesuaian dengan bukti-bukti surat yang diajukan para penggugat sehingga jelas seluruh alat bukti yang diajukan oleh Para Penggugat tidak memiliki nilai kekuatan pembuktian sempurna dan tidak mencapai batas minimum pembuktian.

Untuk membuktikan seluruh dalil bantahannya, Kuasa Hukum Para Tergugat (Tergugat 1, Tergugat 2, dan Tergugat 3) mengajukan alat bukti surat di persidangan antara lain sebagai berikut:

1. Fotokopi Surat Perdamaian tertanggal 17 April 1990 antara INAQ SERIPUDIN dengan AMAQ IRPAN, HAJI MUKSIN, dan INAQ MUKSIN yang diterbitkan oleh Kepala Desa Teros, diberi tanda T-1;

2. Fotokopi Surat Keterangan Jual Sawah Nomor 185/1951 tertanggal 25 Mei 1951, diberi tanda T2;

3. Fotokopi Sertifikat Hak Milik Nomor 257 Desa Teros Kecamatan Selong atas nama MUHRIM, diberi tanda T-3;

4. Fotokopi Putusan Pengadilan Negeri Selong Nomor 22/Pdt.G/1994/PN. Sel, diberi tanda T-4.

Selain bukti-bukti surat, kuasa hukum Para Tergugat (Tergugat 1, Tergugat 2, dan Tergugat 3) juga mengajukan saksi-saksi di bawah sumpah di persidangan antara lain sebagai berikut: 
1. Saksi Sulaiman di bawah sumpah pada pokoknya menerangkan di persidangan sebagai berikut:

- Bahwa tanah obyek sengketa sekarang dikuasai oleh Tergugat I dan kemudian dijual tahunan kepada Tergugat III;

- Bahwa saksi menjelaskan Tergugat I mendapatkan tanah obyek sengketa dari orang tuanya yang bernama AMAQ YUL;

- Baha saksi menjelaskan pernah menandatangani surat pernyataan perdamaian antara HAJI MUKSIN dan TUNIAH di Kantor Desa Teros;

2. Saksi Haji Khairil Anwar di bawah sumpah pada pokoknya menerangkan di persidangan sebagai berikut:

- Bahwa saksi menjelaskan saat ini tanah obyek sengketa dikuasai dan digarap oleh INAQ YUL dan disewakan per tahun kepada AMAQ IR sebesar Rp. 6.000.000,- (enam juta rupiah);

- Bahwa saksi mengatakan INAQ YUL mendapatkan tanah obyek sengketa karena mendapat warisan dari suaminya yang bernama AMAQ SUBUR;

- Bahwa saksi mengatakan AMAQ SUBUR mendapatkan tanah obyek sengketa karena pemberian orang tuanya yang bernama AMAQ RAKMAH, dan AMAQ RAKMAH mendapatkan tanah obyek sengketa dari orang tuanya yang bernama AMAQ SAMAH;

Meskipun keterangan saksi-saksi yang diajukan oleh Kuasa Hukum Para Tergugat (Tergugat 1, Tergugat 2, dan Tergugat 3) yaitu saksi SULAIMAN dan saksi HAJI KHAIRIL di bawah sumpah di persidangan telah bersesuaian satu dengan lainnya yang pada pokoknya menerangkan bahwa tanah obyek sengketa kini telah dikuasai dan digarap oleh INAQ YUL Alias MISLUN yang didapatkan karena pemberian orang tuanya, dan kemudian INAQ YUL Alias MISLUN menjual tahunan tanah obyek sengketa kepada AMAQ IR, namun dalam perkara perdata alat bukti (alat pembuktian) yang utama adalah tulisan, sedangkan dalam suatu perkara pidana kesaksian.

Keadaan yang demikian dapat dimengerti. Seorang yang melakukan suatu tindak pidana selalu menyingkiri adanya suatu bukti sehingga bukti yang harus dicari dari keterangan orang-orang yang secara kebetulan melihat atau mengalami kejadian-kejadian yang merupakan tindak pidana tersebut. Sebaliknya dalam lalu-lintas keperdataan, yaitu dalam jualbeli, utang-piutang, sewa-menyewa dan lain sebagainya, orang-orang itu memang dengan sengaja membuat alat-alat bukti berhubung dengan kemungkinan diperlukannya bukti-bukti itu di kemudian hari. Orang-orang membayar utangnya minta diberikan tanda pembayaran, orang yang membuat suatu perjanjian piutang dengan orang lain, minta dibuatnya perjanjian itu hitam di atas putih, dan lain sebagainya. Dan dengan sendirinya, dalam suatu masyarakat yang sudah maju, tanda-tanda atau bukti-bukti yang paling tepat memanglah tulisan.

Di antara keempat alat bukti surat yang diajukan oleh Kuasa Hukum Para Tergugat (Tergugat 1 , Tergugat 2 , dan Tergugat 3 ) hanya ada dua bukti surat berkualifikasi sebagai akta otentik yaitu bukti surat T-3 dan bukti surat T-4. Bahwa bukti surat T-3 dan bukti surat T-4 jelas merupakan alat bukti akta otentik sebagaimana yang ditegaskan dalam Pasal 1868 KUPerdata yang menyatakan bahwa "Suatu akta otentik ialah suatu akta yang didalam bentuk yang ditentukan oleh undang-undang, dibuat oleh atau di hadapan pegawai-pegawai umum yang berkuasa untuk itu di tempat dimana akta dibuatnya". Berdasarkan Pasal 165 HIR Jo. Pasal 1870 KUHPerdata Jo. Pasal 314 RBg nilai kekuatan pembuktian akta oktentik adalah sempurna, akan tetapi hal itu sepanjang tidak diajukan bukti lawan (tegen bewijs).

Dalam pemeriksaan di persidangan bukti surat T-3 berupa Fotokopi Sertifikat Hak Milik Nomor 257 Desa Teros Kecamatan Selong atas nama MUHRIM dan bukti surat T-4 berupa Fotokopi Putusan Pengadilan Negeri Selong Nomor 22/Pdt.G/1994/PN. Sel telah bersesuaian satu dengan lainnya yang membuktikan AMAQ MUHRIM orang tua dari Tergugat 2 memperoleh tanah tersebut dari LOQ TIMUN berdasarkan waris, dan telah termuat secara sah dan meyakinkan dalam amar putusan Pengadilan 
Negeri Selong Nomor : 22 /Pdt.G/1994 dan tanah obyek sengketa tersebut pada awalnya bersertifikat atas nama LOQ TIMUN.

Meskipun keterangan saksi-saksi yang diajukan oleh Kuasa Hukum Para Tergugat (Tergugat 1, Tergugat 2, dan Tergugat 3) tidak ada satu pun yang memperkuat bukti surat $\mathrm{T}-3$ dan bukti surat $\mathrm{T}-4$, namun mengingat nilai kekuatan pembuktian akta otentik adalah sempurna dan Para Penggugat tidak dapat membantah dengan mengajukan alat bukti surat tersebut maka secara yuridis kedua bukti surat tersebut yaitu bukti surat T-3 dan bukti surat T4 mempunyai nilai kekuatan pembuktian dan bersesuaian satu dengan lainnya sehingga telah mencapai batas minimal pembuktian.

Sedangkan alat bukti yang diajukan oleh Kuasa Hukum Para Tergugat (Tergugat 1, Tergugat 2, dan Tergugat 3) di persidangan berupa bukti surat bertanda T-1 berupa Fotokopi Surat Perdamaian tertanggal 17 April 1990 antara INAQ SERIPUDIN dengan AMAQ IRPAN, HAJI MUKSIN, dan INAQ MUKSIN yang diterbitkan oleh Kepala Desa Teros telah bersesuaian dengn keterangan saksi Sulaiman di bawah sumpah di persidangan yang pada pokoknya menerangkan "bahwa saksi menjelaskan pernah menandatangani surat pernyataan perdamaian antara HAJI MUKSIN dan TUNIAH di Kantor Desa Teros". Namun karena tidak diperkuat dengan keterangan saksi lain yang diajukan oleh Kuasa Hukum Para Tergugat (Tergugat 1, Tergugat 2, dan Tegugat 3), maka keterangan saksi Sulaiman merupakan keterangan satu saksi bukan saksi (unus testis nullus testis) sebagaimana yang telah ditegaskan dalam Pasal 169 HIR, 306 Rbg, dan Pasal 1905 KUHPerdata.

Selain itu bukti surat T-2 berupa Fotokopi Surat Keterangan Jual Sawah Nomor 185/1951 tertangal 25 Mei 1951 bukan merupakan akta otentik melainkan hanya merupakan surat pernyataan. Sesuai dengan kaidah hukum Yurisprudensi tetap Putusan Mahkamah Agung Republik Indonesia Nomor 3901 K/Pdt/1985 tertanggal 29 November 1988 yang pada pokoknya menegaskan bahwa: "surat pernyataan yang merupakan pernyataan atau keterangan belaka dari orang-orang yang memberi pernyataan tanpa diperiksa di persidangan, tidak mempunyai kekuatan pembuktian apa-apa (tidak dapat disamakan dengan kesaksian), dengan kata lain bahwa bilamana pihak-pihak yang membuat surat pernyataan atau surat keterangan tersebut dapat dihadirkan di persidangan dan memberi keterangan bahwa benar surat pernyataan tersebut mempunyai kekuatan pembuktian",

Oleh karena dalam pemeriksaan di persidangan tidak ada satu pun keterangan saksi yang diajukan oleh Kuasa Hukum Para Tergugat (Tergugat 1, Tergugat 2, dan Tergugat 3 ) yang memperkuat bukti surat T-1 dan bukti surat T-2 sehingga kedua bukti surat tersebut tidak mempunyai nilai kekuatan pembuktian yang sempurna. Dengan demikian bukti surat T-1 dan bukti T-2 tidak memiliki nilai kekuatan pembuktian dan tidak mencapai batas minimal pembuktian, oleh karena itu sangat beralasan hukum bukti surat $\mathrm{T}-1$ dan bukti surat $\mathrm{T}-2$ dikesampingkan karena bukti surat $\mathrm{T}-1$ dan bukti surat T-2 tidak memiliki nilai kekuatan pembuktian dan mencapai batas minimal pembuktian.

Berdasarkan seluruh uraian di atas, alatalat bukti yang diajukan oleh Para Penggugat untuk membuktikan seluruh dail gugatannya baik bukti surat maupun surat tidak ada satu pun yang bersesuaian satu dengan lain, sehingga tidak mencapai batas minimal pembuktian. Sebaliknya alat-bukti-bukti yang diajukan oleh Kuasa Hukum Tergugat 1, Tergugat 2, dan Tergugat 3 untuk membuktikan seluruh dalil bantahannya telah bersesuaian satu dengan lainnya dan telah mencapai batas minimal pembuktian.

\section{A. Analisa Hukum Putusan Pengadilan Negeri Selong Nomor : 55/Pdt.G/2020/PN.Sel tanggal 24 November 2020}

Untuk menganalisis apakah putusan hakim itu benar atau tidak, maka yang harus dianalisis adalah pertimbangan hukum putusan hakim. Pertimbangan hukum merupakan jiwa dan intisari putusan. Pertimbangan berisi 
analisis, argumentasi, pendapat, atau kesimpulan hukum dari hakim yang memeriksa perkara. Dalam pertimbangan hukum dikemukakan analisis yang jelas berdasarkan hukum pembuktian mengenai :

1. Apakah alat bukti yang diajukan penggugat dan tergugat memenuhi syarat formil dan materiil,

2. Alat bukti pihak mana yang mencapai batas minimal pembuktian.

3. Dalil gugat apa saja dan dalil bantahan apa saja yang terbukti,

4. Sejauh mana nilai kekuatan pembuktian yang dimiliki para pihak.

Selanjutnya diikuti analisis, hukum apa yang diterapkan menyelesaikan perkara tersebut. Bertitik tolak dari analisis itu, pertimbangan melakukan argumentasi yang objektif dan rasional, pihak mana yang mampu membuktikan dalil gugat atau dalil bantahan sesuai dengan ketentuan hukum yang diterapkan. Dari argumentasi itulah hakim menjelaskan pendapatnya apa saja yang diikuti dan yang tidak, dirumuskan menjadi kesimpulan hukum sebagai dasar alasan landasan penyelesaian perjara yang akan dituangkan dalam diktum putusan. Apabila putusan tidak lengkap dan saksama mendeskripsikan dan mempertimbangkan alat dan nilai kekuatan pembuktian, mengakibatkan putusan dianggap tidak cukup pertimbangan hukumnya atau onvoldoende gemotiveerd, dan putusan tersebut bertentangan dengan Pasal 178 ayat (1) HIR, Pasal 189 RBG.

Untuk mengkonstantir peristiwa, maka peristiwa itu harus dibuktikan kebenarannya. Apa yang dimaksud dengan "membuktikan". Soepomo menerangkan bahwa pembuktian mempunyai arti luas dan arti terbatas. Di dalam arti luas membuktikan berarti memperkuat kesimpulan hakim dengan syarat-syarat bukti yang sah. Di dalam arti yang terbatas membuktikan hanya diperlukan apabila yang dikemukakan oleh penggugat itu dibantah oleh tergugat. Apabila yang tidak dibantah itu tidak perlu dibuktikan. Kebenaran dari apa yang tidak dibantah tidak perlu dibuktikan.
Sudikno Mertokusumo memberikan beberapa pengertian membuktikan antara lain sebagai berikut:

1. Kata membuktikan dikenal dalam arti logis atau ilmiah. Membuktikan di sini berarti memberi kepastian yang bersifat mutlak, karena berlaku bagi setiap orang dan tidak memungkinkan adanya bukti lawan. Berdasarkan suatu axsioma, yaitu asas-asas umum yang dikenal dalam ilmu pengetahuan, dimungkinkan adanya pembuktian yang bersifat mutlak yang tidak memungkinkan adanya pembuktian yang bersifat mutlak yang tidak dimungkinkan adanya pembuktian yang bersifat mutlak yang tidak memungkinkan adanya bukti lawan. Berdasarkan suatu axioma bahwa dua garis yang sejajar tidak mungkin bersilang dapat dibuktikan bahwa dua kaki dari sebuah segitiga tidak mungkin sejajar. Terhadap pembuktian ini tidak dimungkinkan adanya bukti lawan, kecuali itu pembuktian itu berlaku bagi setiap orang. Di sini axioma dihubungkan menurut ketentuan-ketentuan logika dengan pengamatan-pengamatan yang diperoleh dari pengalaman, sehingga diperoleh kesimpulankesimpulan yang memberi kepastian yang bersifat mutlak.

2. Kata membuktikan dikenal juga dalam arti konvensionil. Di sinipun membuktikan berarti juga memberi kepastian, hanya saja bukan kepastian mutlak, melainkan kepastian nisbi atau relatif sifatnya yang mempunyai tingkatantingkatan

a. Kepastian yang didasakan atas perasaan belaka. Karena didasarkan atas perasaan maka kepastian ini bersifat intuitif dan disebut conviction intime.

b. Kepastian yang didasarkan atas pertimbangan akal, maka oleh karena itu disebut conviction raisonnance

3. Membuktikan dalam hukum acara mempunyai arti yuridis. Di dalam ilmu hukum tidak dimungkinkan adanya pembuktian yang logis dan mutlak yang berlaku bagi setiap orang serta menutup segala kemungkinan akan bukti lawan, akan tetapi merupakan pembuktian yang konvensionil yang bersifat khusus. Pembuktian dalam arti yuridis ini hanya berlaku bagi pihakpihak yang berperkara atau yang memperoleh hak dari mereka. Dengan demikian pembuktian dalam arti yuridis tidak menuju kepada kebenaran mutlak. Ada kemungkinannya bahwa 
pengakuan, kesaksian, atau surat-surat itu tidak benar atau palsu atau dipalsukan. Maka dalam hal ini dimungkinkan adanya bukti lawan.

Berdasarkan fakta-fakta persidangan yang terungkap dalam pemeriksaan perkara a-quo tidak ada satupun alat-alat bukti baik bukti surat maupun saksi yang diajukan oleh Para Penggugat di persidangan yang mampu membuktikan dalil gugatannya bahwa Para Tergugat (Tergugat 1, Tergugat 2, dan Tergugat 3) memperoleh tanah obyek sengketa perkara $a$ quo dengan cara melawan hukum dan alat bukti Para Penggugat tidak mencapai batas minimal pembuktian. Sebaliknya Kuasa Hukum Para Tergugat (Tergugat 1, Tergugat 2, dan Tergugat 3) telah mampu membuktikan dalil bantahannya dengan alat bukti baik bukti surat maupun saksi yang diajukan di persidangan dan telah mampu mencapai batas minimal pembuktian.

Dalam pembuktian di persidangan, Kuasa Hukum Para Tergugat (Tergugat 1, Tergugat 2, Tergugat 3) telah mampu membantah dalil gugatan para penggugat dengan bukti surat T-3 berupa Fotokopi Sertifikat Hak Milik Nomor 257 Desa Teros Kecamatan Selong atas nama MUHRIM dan bukti surat T-4 berupa Fotokopi Putusan Pengadilan Negeri Selong Nomor 22/Pdt.G/1994/PN. Sel. Kedua bukti surat yang diajukan oleh Kuasa Hukum Para Tergugat (Tergugat 1, Tergugat 2, dan Tergugat 3) telah bersesuaian satu dengan lainya yang membuktikan AMAQ MUHRIM orang tua dari Tergugat 2 memperoleh tanah tersebut dari LOQ TIMUN berdasarkan waris, dan telah termuat secara sah dan meyakinkan dalam amar putusan Pengadilan Negeri Selong Nomor : 22 /Pdt.G/1994 dan tanah obyek sengketa tersebut pada awalnya bersertifikat atas nama LOQ TIMUN yang kemudian beralih kepada AMAQ MUHRIM orang tua dari Tergugat II selaku ahli waris dari LOQ TIMUN.

Mengenai bukti kepemilikan hak atas tanah dapat dilihat dalam Penjelasan Pasal 24 ayat (1) PP. Nomor. 24 Tahun 1997 Tentang Pendaftaran Tanah yang menyatakan sebagai berikut:
Bukti kepemilikan itu pada dasarnya terdiri dari bukti kepemilikan atas nama pemegang hak pada waktu berlakunya UUPA dan apabila hak tersebut kemudian beralih, bukti peralihan hak berturut-turut sampai ke tangan pemegang hak pada waktu dilakukan pembukuan hak. Alat-alat bukti tertulis yang dimaksudkan dapat berupa :

a. grosse akta hak eigendom yang diterbitkan berdasarkan Overschrijvings Ordonnantie (S.1834-27), yang telah dibubuhi catatan, bahwa hak eigendom yang bersangkutan dikonversi menjadi hak milik; atau

b. grosse akta hak eigendom yang diterbitkan berdasarkan Overschrijvings Ordonnantie (S.1834-27) sejak berlakunya UUPA sampai tanggal pendaftaran tanah dilaksanakan menurut Peraturan Pemerintah Nomor 10 Tahun 1961 di daerah yang bersangkutan; atau

c. surat tanda bukti hak milik yang diterbitkan berdasarkan Peraturan Swapraja yang bersangkutan; atau

d. sertipikat hak milik yang diterbitkan berdasarkan Peraturan Menteri Agraria Nomor 9 Tahun 1959; atau

e. surat keputusan pemberian hak milik dari Pejabat yang berwenang, baik sebelum ataupun sejak berlakunya UUPA, yang tidak disertai kewajiban untuk mendaftarkan hak yang diberikan, tetapi telah dipenuhi semua kewajiban yang disebut di dalamnya; atau

f. akta pemindahan hak yang dibuat di bawah tangan yang dibubuhi tanda kesaksian oleh Kepala Adat/Kepala Desa/Kelurahan yang dibuat sebelum berlakunya Peraturan Pemerintah ini; atau g. akta pemindahan hak atas tanah yang dibuat oleh PPAT, yang tanahnya belum dibukukan; atau

h. akta ikrar wakaf/surat ikrar wakaf yang dibuat sebelum atau sejak mulai dilaksanakan Peraturan Pemerintah Nomor 28 Tahun 1977; atau

i. risalah lelang yang dibuat oleh Pejabat Lelang yang berwenang, yang tanahnya belum dibukukan; atau j. surat penunjukan atau pembelian kaveling tanah pengganti tanah yang diambil oleh Pemerintah atau Pemerintah Daerah; atau

k. petuk Pajak Bumi/Landrente, girik, pipil, kekitir dan Verponding Indonesia sebelum berlakunya Peraturan Pemerintah Nomor 10 Tahun 1961; atau 
1. surat keterangan riwayat tanah yang pernah dibuat oleh Kantor Pelayanan Pajak Bumi dan Bangunan; atau m. lain-lain bentuk alat pembuktian tertulis dengan nama apapun juga sebagaimana dimaksud dalam Pasal II, VI dan VII Ketentuan-ketentuan Konversi UUPA.

Dalam hal bukti tertulis tersebut tidak lengkap atau tidak ada lagi, pembuktian kepemilikan itu dapat dilakukan dengan keterangan saksi atau pernyataan yang bersangkutan yang dapat dipercaya kebenarannya menurut pendapat Panitia Ajudikasi dalam pendaftaran tanah secara sistematik atau oleh Kepala Kantor Pertanahan dalam pendaftaran tanah secara sporadik. Yang dimaksud dengan saksi adalah orang cakap memberi kesaksian dan mengetahui kepemilikan tersebut. 5 Bukti kepemilikan hak atas tanah yang disebutkan dalam Penjelasan Pasal 24 ayat (2) PP Nomor 24 Tahun 1997 Tentang Pendaftaran Tanah tersebut adalah bukti kepemilikan ha katas tanah sebelum diberlakukan UU No. 5 Tahun 1960 Tentang Peraturan Dasar Pokok-Pokok Agraria. Setelah diberlakukannya UU No. 5 Tahun 1960 Tentang Peraturan Dasar Pokok-Pokok Agraria maka bukti kepemilikan hak atas tanah adalah sertifikat hak milik atas tanah sebagaimana yang ditegaskan dalam ketentuan Pasal 1 angka 20 PP. No. 24 Tahun 1997 Tentang Pendaftaran Tanah yang menyatakan "Sertifikat adalah surat tanda bukti sebagaimana dalam Pasal 19 ayat (2) huruf c UUPA untuk hak atas tanah, hak atas pengelolaan, tanah wakaf, hak milik atas satuan rumah susun dan hak tanggungan yang masingmasing sudah dibukukan dalam buku tanah yang bersangkutan".

Dengan demikian pertimbangan hukum Putusan Judex Factie Pengadilan Negeri Selong yang menyatakan bahwa " Menimbang, bahwa berdasarkan pertimbangan hukum sebagaimana telah dijelaskan sebelumnya, maka dengan demikian maka Majelis Hakim berpendapat bahwa para Tergugat adalah pihak yang mempunyai alas hak yang kuat untuk dapat menguasai, mengelola, dam mengolah tanah obyek sengketa telah dikuasai" adalah sah dan benar berdasarkan ketentuan hukum yang berlaku.
Berdasarkan fakta-fakta persidangan, Para Penggugat telah gagal untuk membuktikan seluruh dalil gugatannya dengan alat bukti yang diajukan baik bukti surat dan saksi di persidangan yang mana alat bukti Para Penggugat tidak mencapai batas minimal pembuktian. Sebaliknya Kuasa Hukum Para Terggugat (Tergugat 1, Tergugat 2, dan Tergugat 3) telah mampu membuktikan seluruh dalil bantahan dan alat bukti yang diajukan oleh Kuasa Hukum Para Tergugat (Tergugat 1, Tergugat 2, dan Tergugat 3) bersesuaian satu dengan lain dan telah mampu mencapai batas minimal pembuktian.

Sesuai kaidah hukum yurisprudensi Putusan Mahkamah Agung No. 1574 K/Pdt/1983 yang menyatakan bahwa "Penggugat tidak dapat membuktikan dalil gugatan berdasar alat bukti yang sah, sedangkan tergugat berhasil mempertahankan dalil bantahannya, dengan demikian gugatan ditolak", maka pertimbangan hukum putusan Judex Factie Pengadilan Negeri Selong dalam perkara $a$-quo yang mengesampingkan bukti-bukti dari Para Penggugat adalah sah dan benar berdasarkan hukum karena berdasarkan fakta-fakta persidangan Para Penggugat tidak dapat membuktikan seluruh dalil gugatannya dan Kuasa Hukum Para Tergugat (Tergugat 1, Tergugat 2, dan Tergugat 3) telah mampu membuktikan seluruh dalil bantahannya.

\section{KESIMPULAN}

Berdasarkan seluruh uraian pembahasan di atas dapat disimpulkan bahwa alat-alat bukti yang diajukan oleh Para Penggugat untuk membuktikan seluruh dalil gugatannya baik bukti surat maupun surat tidak ada satu pun yang bersesuaian satu dengan lain, sehingga tidak mencapai batas minimal pembuktian. Sebaliknya alat-bukti-bukti yang diajukan oleh Kuasa Hukum Tergugat 1, Tergugat 2, dan Tergugat 3 untuk membuktikan seluruh dalil bantahannya telah bersesuaian satu dengan lainnya dan telah mencapai batas minimal pembuktian. 
Berdasarkan kaidah hukum Yurisprudensi Putusan Mahkamah Agung No. $1574 \mathrm{~K} / \mathrm{Pdt} / 1983$ yang menyatakan bahwa "Penggugat tidak dapat membuktikan dalil gugatan berdasar alat bukti yang sah, sedangkan tergugat berhasil mempertahankan dalil bantahannya, dengan demikian gugatan ditolak", maka Putusan Judex Factie Pengadilan Negeri Selong dalam perkara $a$-quo adalah sah dan benar berdasarkan hukum karena berdasarkan fakta-fakta persidangan Para Penggugat tidak dapat membuktikan seluruh dalil gugatannya dan Kuasa Hukum Para Tergugat (Tergugat 1, Tergugat 2, dan Tergugat 3) telah mampu membuktikan seluruh dalil bantahannya.

Dengan demikian dalam pembuktian suatu perkara yang menentukan adalah apakah alat-alat bukti yang diajukan oleh para pihak yang berperkara telah memenuhi syarat formil dan materiil serta telah mencapai batas minimal pembuktian untuk membuktikan dalil-dalil baik dalam gugatan maupun eksepsi dan jawaban sesuai dengan adagium hukum pembuktian yang tersirat dalam ketentuan pasal 163 HIR jo. pasal $283 \mathrm{RBg}$ jo. pasal 1865 KUHPerdata yang berbunyi "Barangsiapa yang mengaku mempunyai hak atau mendasarkan pada suatu peristiwa untuk menguatkan haknya itu atau untuk menyangkal hak orang lain, harus membuktikan adanya hak atau peristiwa itu".

\section{DAFTAR PUSTAKA}

\section{A. Buku}

Fuady, Munir, Perbuatan Melawan Hukum (Pendekatan Kontemporer), Bandung: PT. Citra Aditya Bakti, 2020

Harahap, M. Yahya, Hukum Acara Perdata, Gugatan, Persidangan, Penyitaan, Pembuktian, dan Putusan Pengadilan, Jakarta: Sinar Grafika, 2005

Harsono, Boedi. Hukum Agraria Indonesia : Sejarah Pembentukan UU Agraria, Isi dan Pelaksananya, Cet. 12, Jakarta : Djambatan, 2008.
Mertokusumo, Sudikno Mertokusumo, Hukum Acara Perdata Indonesia, Edisi Ketujuh, Yogyakarta: Liberty, 2006

Ny. Retnowulan Sutantio dan Iskandar Oeripkartawina, Hukum Acara Perdata dalam Teori dan Praktek, Bandung: Mandar Maju, 2005

R. Subekti, Hukum Pembuktian, Jakarta: PT. Pradnya Paramita, 2005

Soepomo, Hukum Acara Perdata Pengadilan Negeri, Jakarta: Bina Aksara, 1983

\section{B. Peraturan Perundang-undangan}

HIR

$\mathrm{RBg}$

KUHPerdata

UU No. 5 Tahun 1960 Tentang Peraturan Dasar Pokok-Pokok Agraria

PP. No. 24 Tahun 1997 Tentang Pendaftaran Tanah

C. Putusan Pengadilan dan Yurisprudensi

Putusan Pengadilan Negeri Selong Nomor 55/Pdt.G/2020/PN. Sel tanggal 24 November 2020

Yurisprudensi Putusan MARI No. 34 K/Sip/1960 tanggal 10 Februari 1960

Yurisprudensi Putusan Mahkamah Agung No. 1574 K/Pdt/1983

Yurisprudensi tetap Putusan Mahkamah Agung Republik Indonesia Nomor 3901 K/ Pdt/1985 tertanggal 29 November 1988 